\title{
Reactive Processing of Environmentally Conscious, Biomorphic Ceramics from Natural Wood Precursors
}

\author{
M. Singh and Bo-Moon Yee* \\ QSS Group, Inc. \\ NASA Glenn Research Center \\ Cleveland, OH 44135 (USA)
}

\begin{abstract}
Environmentally conscious, biomorphic ceramics (Ecoceramics) are a new class of materials that are manufactured from renewable resources and wastes. In this study, silicon carbide and oxide-based biomorphic ceramics have been fabricated from pine and jelutong wood precursors. A carbonaceous preform is produced through wood pyrolysis and subsequent infiltration with oxides $\left(\mathrm{ZrO}_{2}\right.$ sols $)$ and liquid silicon to form ceramics. These biomorphic ceramics show a wide variety of microstructures, densities, and hardness behavior that are determined by the type of wood and infiltrants selected.
\end{abstract}

\section{Introduction}

In recent years, there has been an increasing interest in using biomimetic-based processing approaches to fabricate a variety of oxide and non-oxide based structural and functional materials. Environmentally conscious ceramics (Ecoceramics) are a class of materials that can be manufactured from renewable resources such as wood. Through pyrolysis of wood, a carbonaceous preform is produced. It is then infiltrated with oxides and non-oxides that react to form a strong and tough ceramic or composite that can be used for a variety of applications including filters and catalyst support, automotive components, tooling and wear components, armor, and lightweight, porous ceramics for aerospace systems [1-12]. Ecoceramics have several benefits over traditional ceramics.

\footnotetext{
his report is a preprint of an article submitted to journal for publication. Because of changes that lay be made before formal publication, this reprint is made available with the understanding lat it will not be cited or reproduced without the ermission of the author.
}

\footnotetext{
* Summer Intern, Currently at University of Illinois at Urbana-Champaign, IL
} 
The entire manufacturing process can be performed under $1450^{\circ} \mathrm{C}$, so the total amount of energy consumed is low. Another benefit is the wide variety of microstructures that can be obtained, determined by the type of wood selected. The use of wood provides a lowcost starting material that has near-net and complex shape capabilities, instead of the simple shapes that are normally produced by traditional ceramic processing techniques.

With the many benefits of using wood as a material, it is critical to have a greater understanding of its structure. Wood is classified as a composite material that behaves anisotropically with a cell morphology that varies with each species [5]. It is composed of cellulose, hemicellulose, and lignin, which decompose to produce char in the form of amorphous carbon during pyrolysis and produces an anisotropic cellular structure. Further information on pyrolysis can be found in the literature [13]. Anisotropy in wood is the result of the orientation and alignment of cells and cell walls, as well as variation in density [14].

Trees are separated into two classes: hardwoods and softwoods. The terms hardwood and softwood do not refer to the hardness of the wood, but relates to the anatomical structure of the tree. Both classes of woods have tubular cells that run in the direction of tree growth, but hardwoods have large porous structures that provide channels for water or sap, while softwoods do not. The channels that run parallel to the growth direction are referred to as longitudinal cells, while ray cells run radially outwards from the center of the tree. Longitudinal cells out number the ray cells to varying degrees among species, but the ray cells contribute to the strength in the radial direction [14].

In this research, two types of wood, one from each class, were investigated. Jelutong (Dyera costulata) is an imported hardwood from Malaysia that is used mainly for its latex production for chewing gum. With a low density and easy workability, jelutong is ideal for infiltration of oxide sols and molten silicon in a complex-shaped component. Eastern white pine (Pinus strobus), a softwood, is typically used as a structural element [15]. In this paper, wood pyrolysis, infiltration behavior, and microstructure of biomorphic ceramics made from jelutong and pine will be presented. 


\section{Experimental Procedures}

One block of jelutong and three blocks of pine were dried in an oven at $100^{\circ} \mathrm{C}$ and pyrolyzed in an argon atmosphere. Pyrolysis is the decomposition of a wood heated in an inert atmosphere to release volatiles, leaving behind a carbonaceous preform with celllike structures. The jelutong blocks measured $15 \mathrm{~cm} \times 4.5 \mathrm{~cm} \times 4.5 \mathrm{~cm}$ while the dimensions of the pine blocks were $14 \mathrm{~cm} \times 3.5 \mathrm{~cm} \times 3 \mathrm{~cm}$. The blocks were placed in a Thermcraft tube furnace and pyrolyzed up to $1000^{\circ} \mathrm{C}$. Afterwards, the blocks were cut into approximately $0.4 \mathrm{~cm}$ thick slices that were to be infiltrated. To investigate the effects of higher pyrolysis temperatures on the pore structure, samples of jelutong and pine were heat-treated at $1400^{\circ} \mathrm{C}$ and $1800^{\circ} \mathrm{C}$ for one hour after pyrolysis.

A characterization of the pyrolysis process was performed using thermogravimetry (TG) and differential scanning calorimetry (DSC). These two techniques were executed simultaneously to measure the change in sample mass with temperature as well as changes in enthalpy that occur during pyrolysis. The Netzsch Thermische Analyse STA 409C was used in this process, with alumina powder as the reference sample.

The carbonaceous preforms were infiltrated with $\mathrm{Si}$ at $1460^{\circ} \mathrm{C}$ for one hour in a vacuum Centorr Furnace. Both carbon and $\mathrm{SiC}$ samples were infiltrated with $\mathrm{ZrO}_{2}$ sol in a Buehler Vacuum Impregnation chamber. After infiltration, the samples were dried in a furnace at $85^{\circ} \mathrm{C}$ for several hours and then placed in a tube furnace for calcination up to $400^{\circ} \mathrm{C}$. This process was repeated up to five times. To gain knowledge of the progress of the infiltration, some samples were infiltrated only one or three times.

The original pore structure of the two types of wood were analyzed by viewing a fresh fracture surface of jelutong and pine using the scanning electron microscope (SEM). Images were taken of two orientations of the carbon structures: perpendicular and parallel to the growth direction of the tree. The growth direction is equivalent to the longitudinal axis of the trunk. The SEM was also used for the analysis of the carbon preforms infiltrated with $\mathrm{ZrO}_{2}$, the porous $\mathrm{SiC}$ coated with $\mathrm{ZrO}_{2}$ (one, three, and five times), and 
samples heat-treated at $1800^{\circ} \mathrm{C}$. Si and $\mathrm{SiC}$ were not readily distinguishable in the SEM images; therefore the samples infiltrated with only Si were viewed with the light optical microscope (LOM). The LOM was also used to characterize the porous $\mathrm{SiC}$ samples coated with $\mathrm{ZrO}_{2}$.

The phases present in the samples that were infiltrated three times with $\mathrm{ZrO}_{2}$ were determined using X-ray diffraction on samples ground to a powder using a mortar and pestle. The heat-treated samples were also analyzed to determine the nature of carbon in pyrolyzed wood.

Microhardness tests were performed using a Knoop indenter with a $500 \mathrm{~g}$ load to measure the hardness in the following regions: reaction formed $\mathrm{SiC}, \mathrm{Si}$, and the interface of $\mathrm{SiC}$ and Si. A total of six samples were tested: pine (perpendicular to the growth direction), jelutong (perpendicular and parallel to the growth direction), and three porous $\mathrm{SiC}$ samples from jelutong, that were infiltrated with $\mathrm{ZrO}_{2}$ (one, three, and five times). Five indentations were made in each region and the average Knoop hardness value for each region in each sample was calculated.

\section{Results and Discussion}

Pyrolysis: After pyrolysis, the blocks retained their shape, but decreased in size. The pyrolysis shrinkage in jelutong was $25 \%$ in dimensions and the total volume decreased by $60 \%$. The dimensions of the blocks of pine decreased roughly by $22 \%$, while the total volume was reduced by $50 \%$. Cracks appeared in the pine blocks due to shrinkage stress created from the exterior of the blocks decomposing at a faster rate than the middle, but did not appear in the jelutong block. The heating rates are crucial to the integrity of the pyrolyzed blocks, and each type of wood requires different rates that are dependent on the wood's density [14].

Thermal Analysis: The TG curves for both woods are plotted on the same graph for comparison and are shown in Figure 1. Figure 2 is a plot of both DSC curves. As can be 
seen from both TG curves, the majority of the mass loss during pyrolysis occurred between $200^{\circ} \mathrm{C}$ and $400^{\circ} \mathrm{C}$. The peaks in the DSC curves indicate that the reactions and gas evolutions during pyrolysis occur in the same temperature range of $200^{\circ} \mathrm{C}$ to $400^{\circ} \mathrm{C}$. Similarities in the pyrolysis process exist between the woods. The initial weight loss begins around $100^{\circ} \mathrm{C}$, where the moisture is removed, and ends at about $170^{\circ} \mathrm{C}$. The second step in the weight loss process occurs by the decomposition of hemicellulose $\left(190-280^{\circ} \mathrm{C}\right)$ and the release of volatile products. At a slightly higher temperature range of $280-500^{\circ} \mathrm{C}$, a majority of the weight loss occurs due to the decomposition of cellulose and lignin, leaving behind a carbon preform. After $500^{\circ} \mathrm{C}$, very little weight loss occurs, which can be seen in Figure 2. DSC curves demonstrate the endothermic and exothermic nature of the reactions. While the TGA curves are quite similar for both woods, the DSC curves have slight variations due to the varying chemical composition between jelutong and pine [16]. Details on the reactions can be found in the literature [13].

Porous $\mathrm{C}$ and SiC: The microstructure of the pyrolyzed woods and $\mathrm{Si}$ infiltrated samples are shown in Figures 3-6. In Figures 3 and 4, the white outlines are carbon and the black areas are the pores. Figure $3 \mathrm{a}$ shows that pyrolyzed jelutong has a non-uniform pore structure, with sets of large pores within surrounding smaller pores of varying size. The ray cells in jelutong are evident in Figure $3 \mathrm{~b}$, which shows the view that is parallel to the direction of tree growth.

The amount of ray cells in pine (Figure 4b) is less than in jelutong, indicating that the strength of pine would be higher than jelutong in the direction that is perpendicular to the growth. Figure $4 \mathrm{a}$ shows that pine has a uniform pore structure, since the pores are similar in size and shape.

When the carbon preforms were infiltrated with silicon, the silicon reacted with the carbon to form silicon carbide (SiC). In Figures 5 and 6, the dark gray outlines represent the $\mathrm{SiC}$, while the light gray areas are excess silicon. The reacted $\mathrm{SiC}$ retained the original structure of the wood. Some of the large pores were not completely filled with $\mathrm{Si}$, therefore the final material is not completely dense. Density variation existed across 
all of the infiltrated samples, which would affect the results of the hardness tests. Upon further treatment, the excess silicon can be removed, leaving behind a porous $\mathrm{SiC}$ structure.

The carbon samples heat-treated at $1800^{\circ} \mathrm{C}$ are shown in Figure 7. At $1400^{\circ} \mathrm{C}$, no changes in structure were apparent, but at the higher temperature, the cell walls underwent a shape transformation. Partial graphitization occurred at $1800^{\circ} \mathrm{C}$ and with the ordering of the carbon structure, the pore morphology changed slightly and decreased in diameter by an average of roughly $20 \%$. This occurrence would come into effect if the infiltration process of other materials were performed at higher temperatures than $1500^{\circ} \mathrm{C}$. The orientation of the graphite may influence the mechanical properties of the final product [17].

Infiltration of sols in $\mathbf{C}$ and $\mathrm{SiC}$ : Jelutong samples infiltrated with $\mathrm{ZrO}_{2}$ three and five times are shown in Figures 8a and 8b, respectively. The original structure of jelutong can still be seen, but $\mathrm{ZrO}_{2}$ now coats it and the pores are filled with crystallized $\mathrm{ZrO}_{2}$. As the number of infiltrations increased, the amount of oxide deposition increased, eventually completely filling the pores. The same trend was observed in the pine samples infiltrated with $\mathrm{ZrO}_{2}$ three and five times. The results of these infiltrations can be seen in Figures 9a and $9 \mathrm{~b}$. As with three infiltrations in jelutong, the original structure of pine can still be seen, but after five infiltrations, cracks formed in the structure.

Prior to the carbon samples being infiltrated, the preforms had similar physical densities around $0.3 \mathrm{~g} / \mathrm{cm}^{3}$, determined by measuring the dimensions and weight of the sample. After the third infiltration, however, the amount of mass gain of pine leveled off while jelutong continued to accumulate mass. The large sets of pores in the jelutong structure provided additional areas for the $\mathrm{ZrO}_{2}$ infiltration even after the smaller pores were filled. Figure 10 is a plot of the geometric densities of jelutong and pine after each infiltration. The final densities of the materials vary depending on the type of wood selected for the precursor material. It is controlled by the microstructure of the wood. 
$\mathrm{SiC}$ samples from jelutong were also infiltrated with $\mathrm{ZrO}_{2}$ one, three, and five times. After the silicon infiltration, the large pores were not completely filled, so the oxide mostly deposited in the large pores, as well as coated the $\mathrm{SiC}$ structure. As the number of these infiltrations increased, the amount of $\mathrm{ZrO}_{2}$ in the large pores increased, which can be seen in Figure 11.

X-Ray Diffraction: The carbon samples infiltrated with $\mathrm{ZrO}_{2}$ three times were analyzed by X-ray diffraction to determine the phases present. Both types of wood produced the same results. A plot of the intensity of the beam versus the Bragg angle is shown in Figure 12. The phase predominantly present was monoclinic $\mathrm{ZrO}_{2}$, but traces of cubic $\mathrm{ZrO}_{2}$ were also detected.

Without heat-treatment at higher temperatures, the samples consisted of amorphous carbon that was indistinguishable from the sample holder during $\mathrm{x}$-ray diffraction. Scans of the heat-treated samples are displayed in Figure 13, along with the scan of the sample holder for reference. As the heat-treatment temperature increased, the peaks became more defined due to the atomic ordering of the carbon [17].

Microhardness: The average values from the microhardness tests are displayed in Table I and plotted in Figure 14. The average Knoop hardness values for the $\mathrm{ZrO}_{2}$-coated $\mathrm{SiC}$ decreased from $1500 \mathrm{Hk}$ to $1400 \mathrm{Hk}$ as the number of oxide infiltrations increased, as expected due to the softer oxide coating. The lowest hardness value for $\mathrm{SiC}$ in the jelutong sample tested parallel to the growth direction is believed to be attributable to the orientation of the fibers. Wood is an anisotropic material whose properties are dependent upon the direction of the loading, leading to a preferred orientation of the porous structure.

The total average Knoop hardness value of all $\mathrm{SiC}$ areas was $1510 \mathrm{Hk}$, which is significantly lower than the documented value of $2480 \mathrm{Hk}$, possibly due to the difference in densities of the infiltrated sample and monolithic $\mathrm{SiC}$ [18]. Indentations in pure $\mathrm{SiC}$ were hard to perform due to the size of the $\mathrm{SiC}$ areas relative to the size of the indenter; 
therefore, accurate hardness values were difficult to obtain. The areas filled with excess Si were larger in size, making indentations in pure Si easier to make. The total average Knoop hardness value for $\mathrm{Si}$ was $920 \mathrm{Hk}$, which is closer in range to the recorded hardness values of 950-1150 $\mathrm{Hk}$ [19]. At the interface of $\mathrm{SiC}$ and $\mathrm{Si}$, the total average Knoop hardness value fell in between the values of SiC and Si, as expected, at $1230 \mathrm{Hk}$.

\section{Conclusions}

Ecoceramics provide opportunities for expanded designs and applications since they have near-net and complex shape capabilities, variable microstructures, are friendly to the environment, and are economically favorable in comparison with traditional ceramics. Starting with natural wood, the desired final shape of the component can be obtained, and retains that shape all through the process. The microstructure of the original biostructure is maintained throughout the procedure, which allows for knowledge of the resulting properties of the product. Finally, the starting materials used are inexpensive and a renewable resource.

\section{Acknowledgements}

The author would like to thank Richard Dacek, John Setlock, Ralph Garlick, and Myles McQuater for their technical assistance. Technical discussions with Professor Julian Martinez-Fernandez and the critical review of the manuscript by Mr. James D. Kiser are also acknowledged.

\section{References}

[1] J.E. Mark and P.D. Calvert. "Biomimetic, Hybrid and In-Situ Composites." Mater. Sci. and Engg., C1, 159 (1994).

[2] T. Ota, M. Takahashi, T. Hibi, M. Ozawa, and H. Suzuki. "Biomimetic Process for Producing SiC Wood.” J. Am. Ceram. Soc., 78 (1995) 3409.

[3] P. Greil, T. Lifka, and A. Kaindl. "Biomorphic Silicon Carbide Ceramics from Wood: I and II.” J. Eur. Ceram. Soc., 18, (1998) 1961. 
[4] P. Griel. "Biomorphic Ceramics from Lignocellulosics." J. Eur. Ceram. Soc., 21 (2001) 105-118.

[5] H. Sieber, C. Hoffmann, A. Kaindl, P. Greil. Biomorphic Cellular Ceramics, Advanced Engineering Materials, Vol. 2, No. 3, (2000) pp. 105-109.

[6] D.-W. Shin, S.S. Park, Y.-H. Choa and K. Niihara. "Silicon/Silicon Carbide Composites Fabricated by Infiltration of a Silicon Melt into Charcoal." J. Am. Ceram. Soc., 82, 3251 (1999).

[7] D.C. Nagle and C.E. Byrne. "Carbonized Wood and Materials Formed Therefrom." US Patent 6,124,028 (2000).

[8] M. Singh. "Environment Conscious Ceramics (Ecoceramics)." Ceram. Sci. Engg. Proc., 21 [4] 39-44 (2000).

[9] J. Martinez-Fernandez, F.M. Valeria-Feria and M. Singh. "High Temperature Compressive Mechanical Behavior of Biomorphic Silicon Carbide Ceramics." Scripta Materialia, 43, 813-818 (2000).

[10] G. Qiao, R. Ma, N. Cai, C. Zhang, and Z. Jin. "Mechanical Properties and Microstrucutre of Si/SiC Materials Derived from Native Wood." Materi. Sci. Engg., A 323 (2002) 301-305.

[11] M. Singh. "Environment Conscious Ceramics (Ecoceramics)." NASA/TM-2001210605, NASA Glenn Research Center, Cleveland, OH.

[12] M. Singh. "Ecoceramics: Ceramics from Wood." Advanced Materials and Processes, March 2002, ASM International, Materials Park, OH.

[13] S. Sinha, A. Jhalani, M.R. Ravi, A. Ray, Modeling of Pyrolysis in Wood: a Review, SESI Journal 10(1), 2000, pp. 41-62.

[14] C.E. Byrne, D.C. Nagle. "Carbonization of Wood for Advanced Materials Applications.” Carbon, Vol. 35, No. 2, 1997, pp. 259-266.

[15] Wood Handbook - Wood as an Engineering Material. Forest Products Laboratory. 1999. Gen. Tech. Rep. FPL-GTR-113. Madison, WI: U.S. Department of Agriculture, Forest Service, Forest Products Laboratory. 463 p.

[16] M. Singh and J.A. Salem. "Mechanical Properties and Microstructure of Biomorphic Silicon Carbide Ceramics Fabricated from Wood Precursors." J. Eur. Ceram. Soc., Vol. 22, Nos.14-15, 2002, pp. 2709-1718. 
[17] C.E. Byrne, D.C. Nagle. "Carbonized Wood Monoliths - Characterization." Carbon Vol. 35, No. 2, 1997, pp. 267-273.

[18] University of Michigan, Knoop Hardness Number, KHN http://www.lib.umich.edu/dentlib/Dental_tables/Knoophard.html

[19] W.R. Runyan. Silicon Semiconductor Technology. New York, McGraw-Hill Book Company, 1965. 


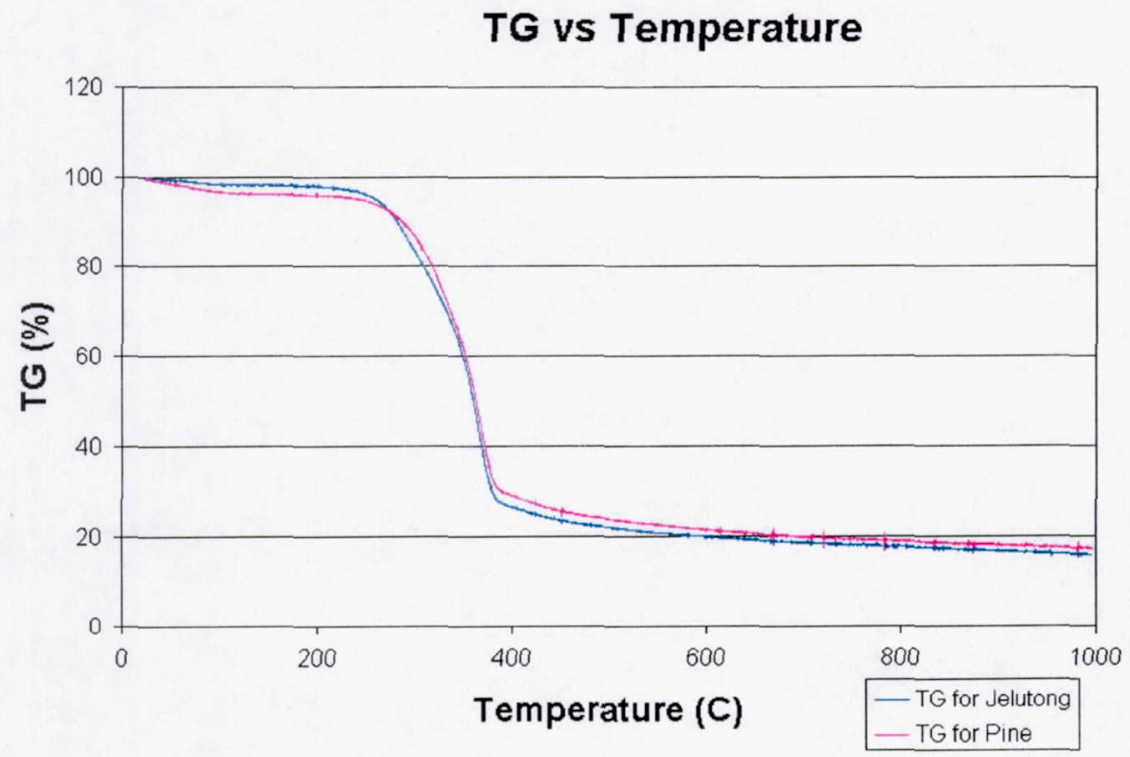

Figure 1. Thermogravimetry curves for jelutong and pine wood.

DSC vs. Temperature

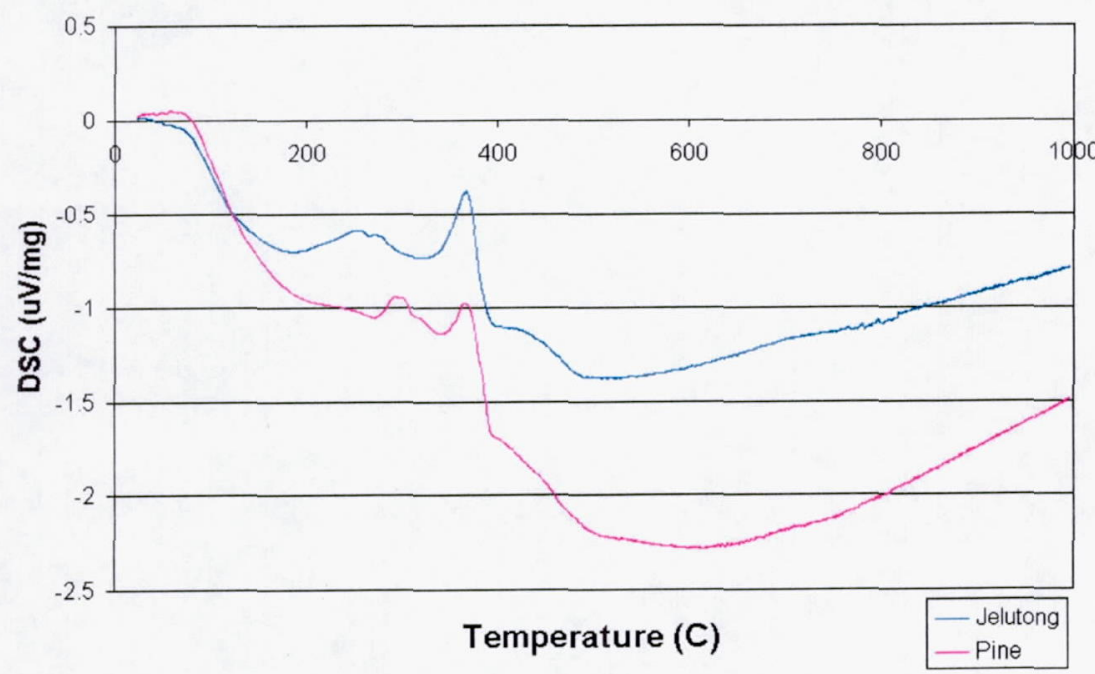

Figure 2. Differential Scanning Calorimetry (DSC) curves for jelutong and pine wood. 

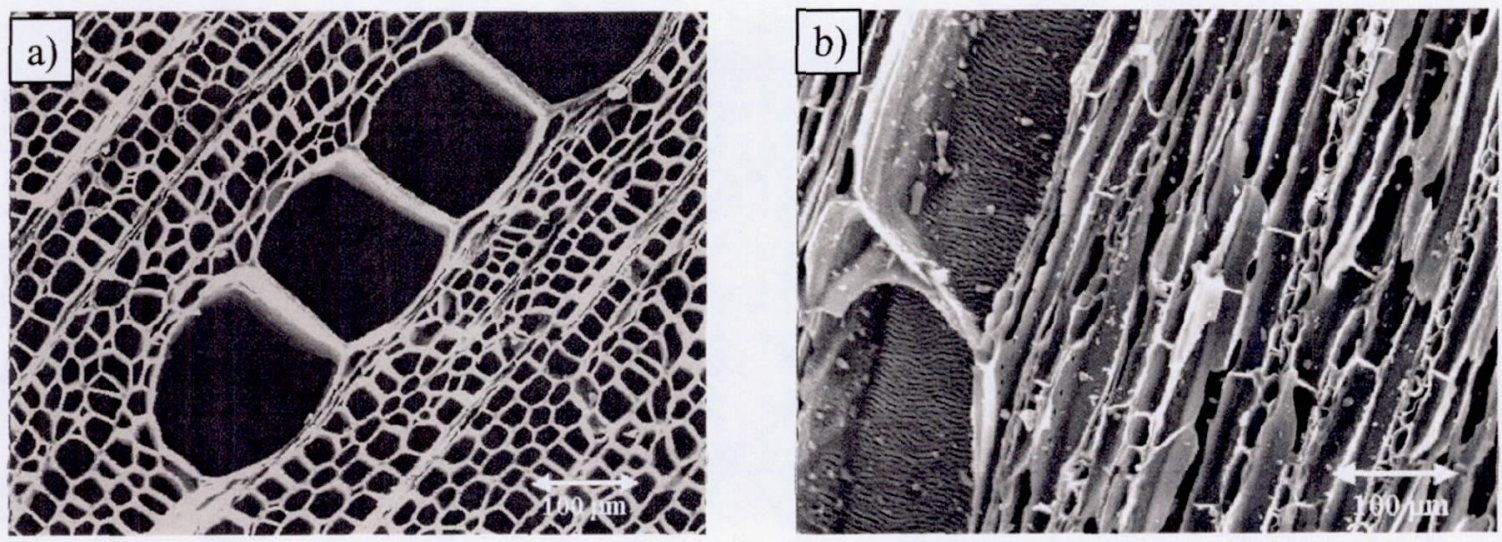

Figure 3. Microstructure of pyrolyzed jelutong in a) axial direction and b) radial direction.
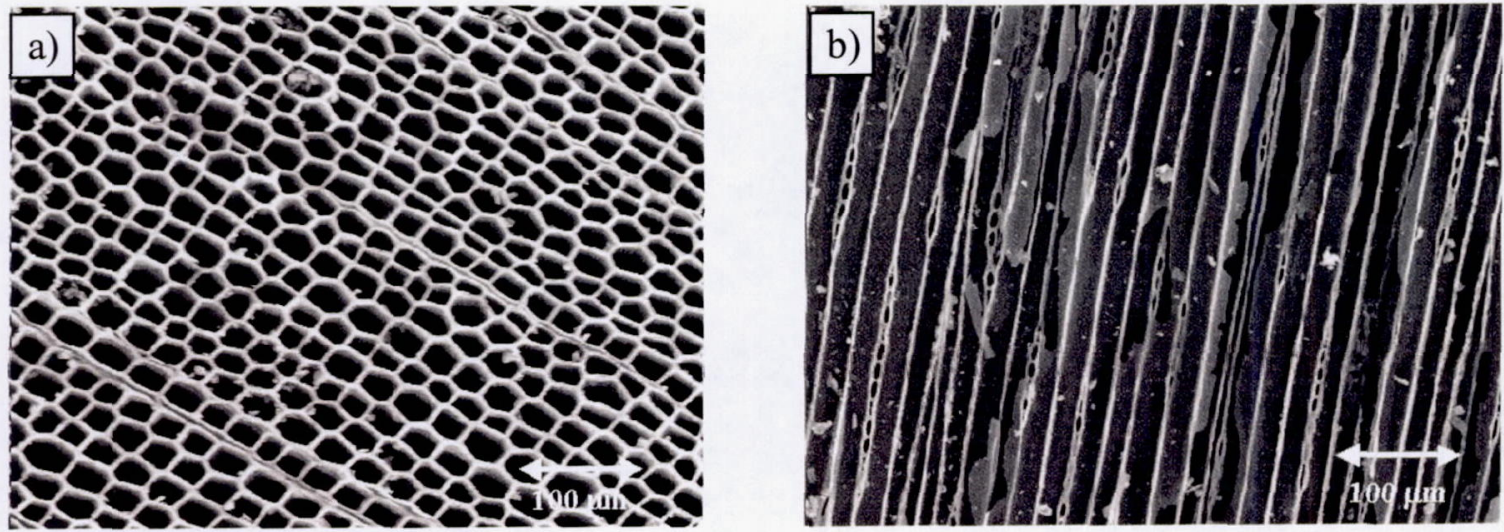

Figure 4. Microstructure of pyrolyzed pine in a) axial direction and b) radial direction.
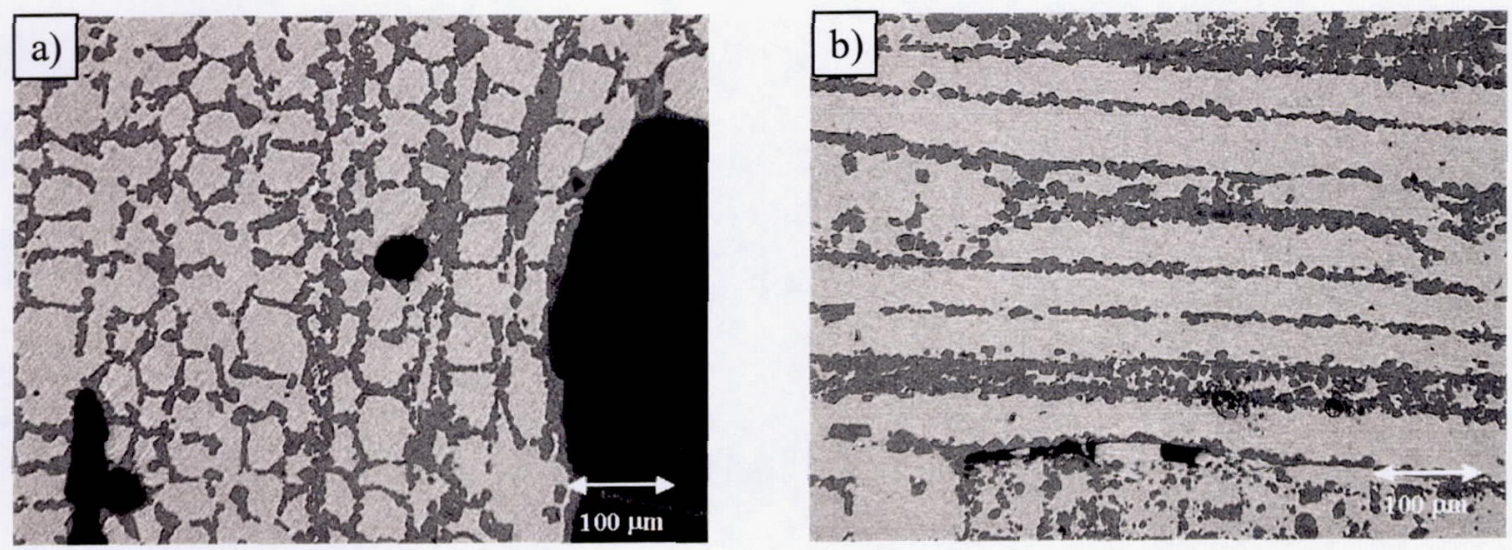

Figure 5. Microstructure of jelutong infiltrated with molten $\mathrm{Si}$ in a) axial direction and b) radial direction. 

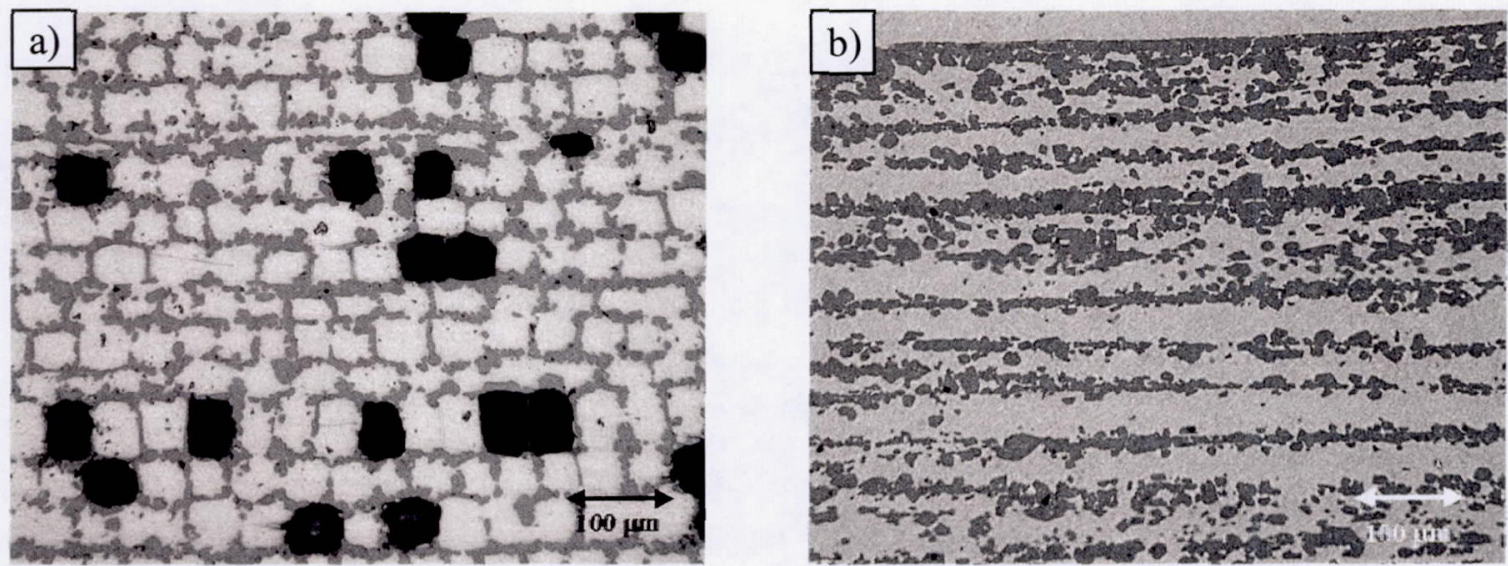

Figure 6. Microstructure of pine infiltrated with molten Si in the a) axial direction and b) radial direction.

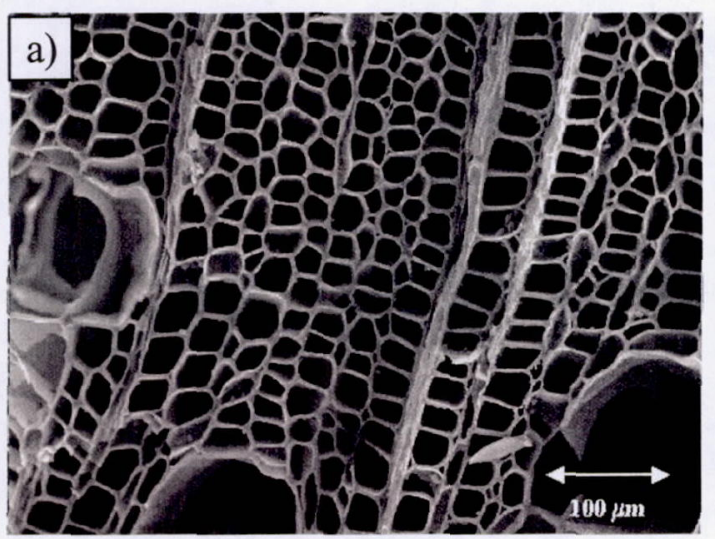

Figure 7. Microstructure of pyrolyzed a) jelutong and b) pine heat treated at $1800^{\circ} \mathrm{C}$.
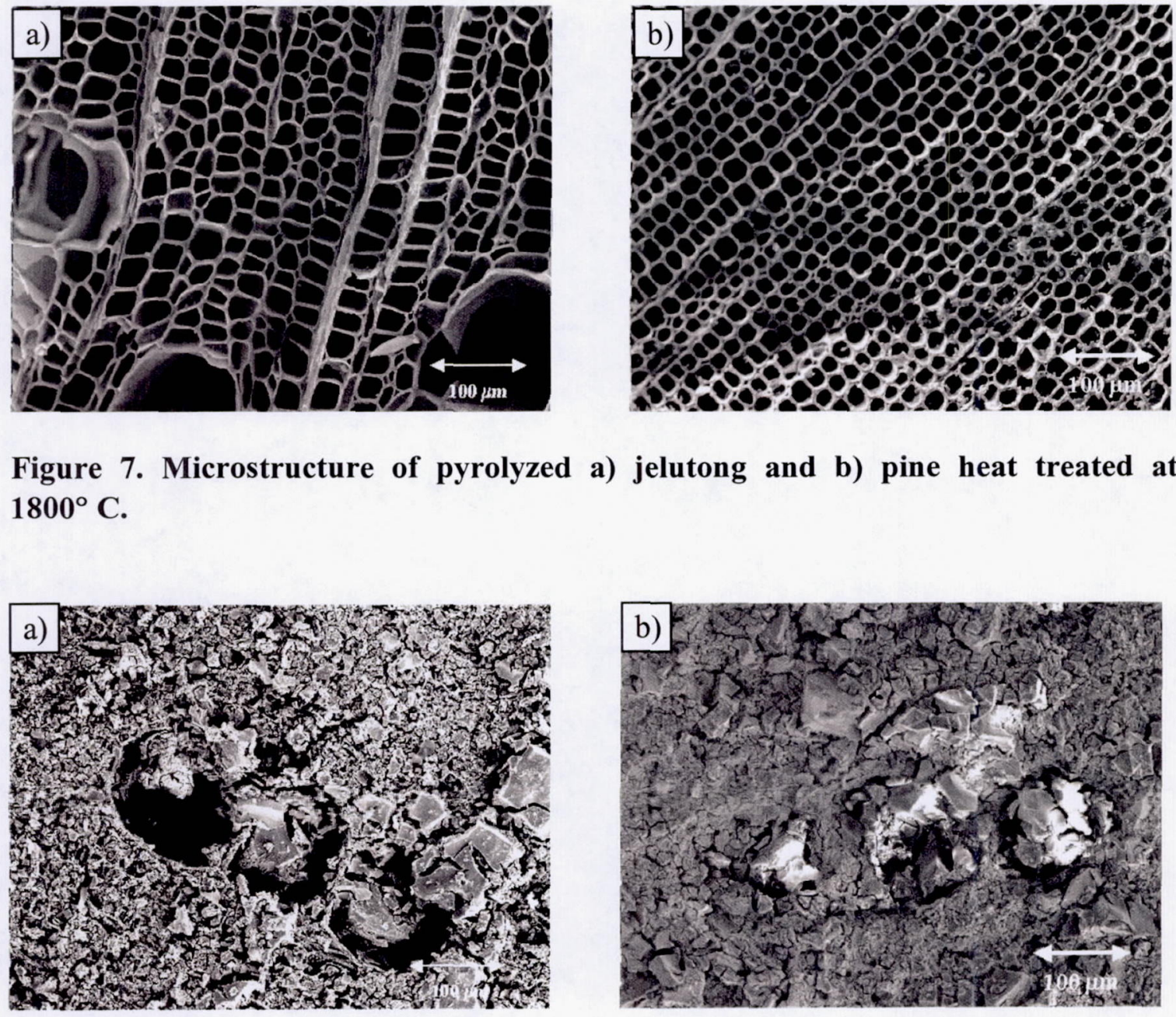

Figure 8. Microstructure of jelutong infiltrated with $\mathrm{ZrO}_{2}$ a) 3 and b) 5 times in the axial direction. 

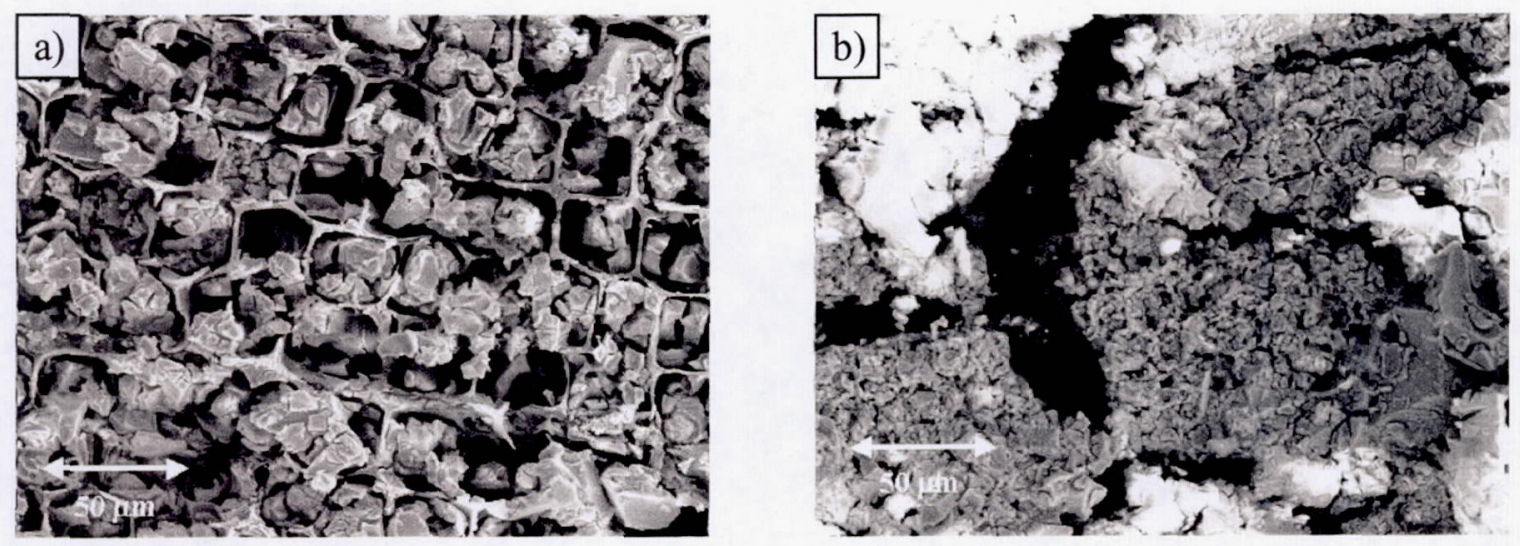

Figure 9. Microstructure of pine infiltrated with $\mathrm{ZrO}_{2}$ a) 3 and b) 5 times in the axial direction.

\section{Densities of Carbonaceous Jelutong and Pine}

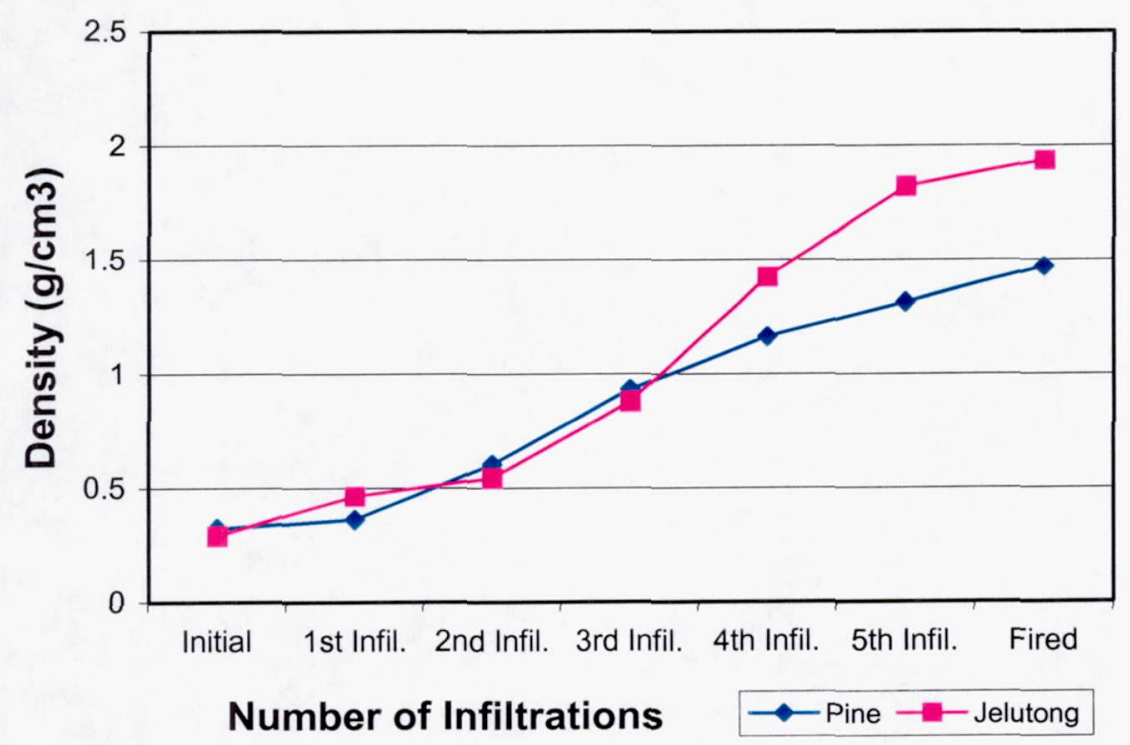

Figure 10. Plot of the densities of carbonaceous jelutong and pine after each infiltration of $\mathrm{ZrO}_{2}$. 


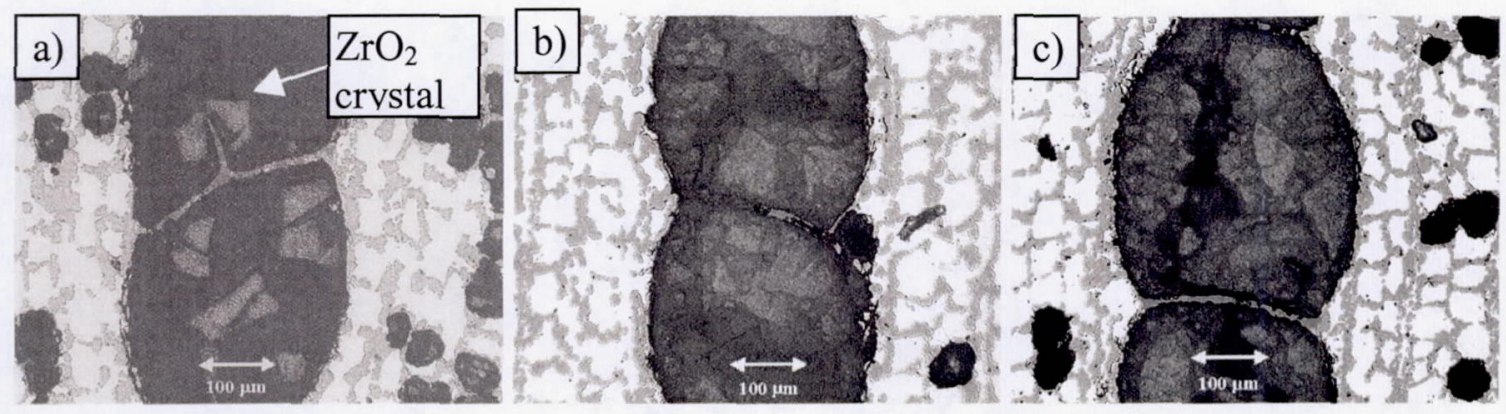

Figure 11. Microstructure of jelutong based $\mathrm{SiC}$ infiltrated with $\mathrm{ZrO}_{2}$ a) one, b) three, and c) five times.

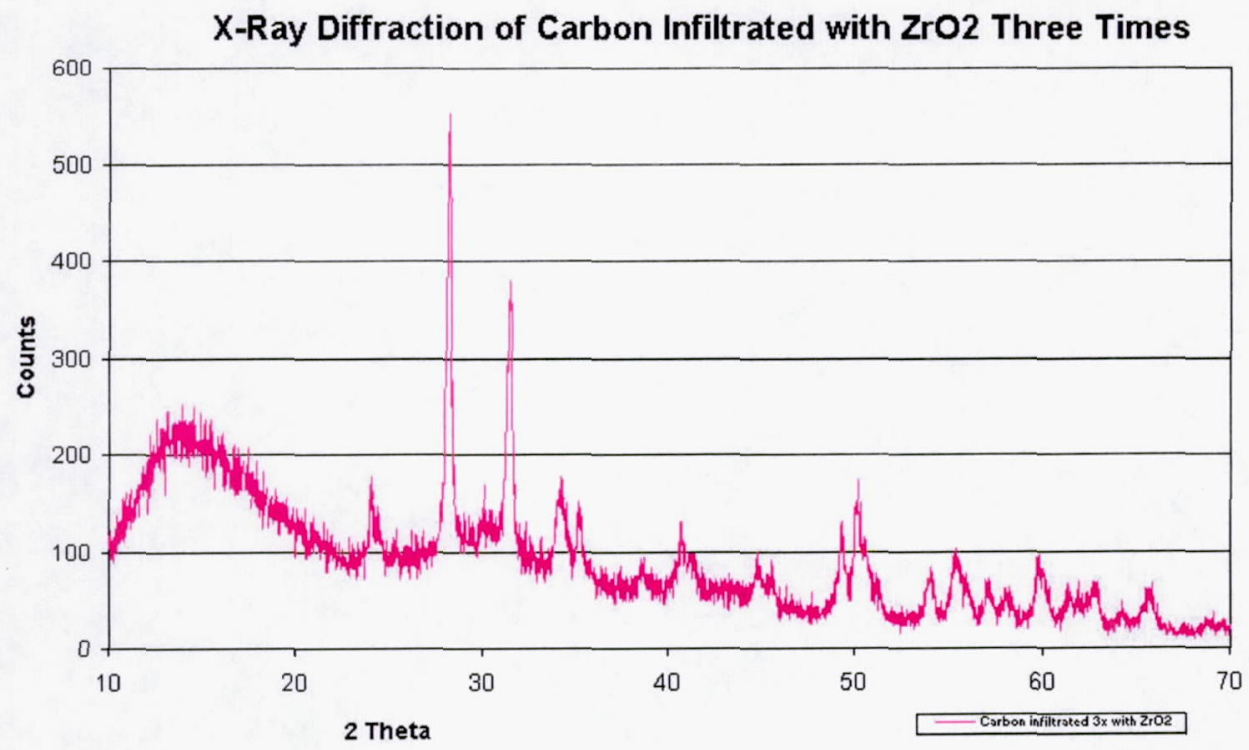

Figure 12. X-ray diffraction scan of carbon preform infiltrated with $\mathrm{ZrO}_{2}$ three times. 


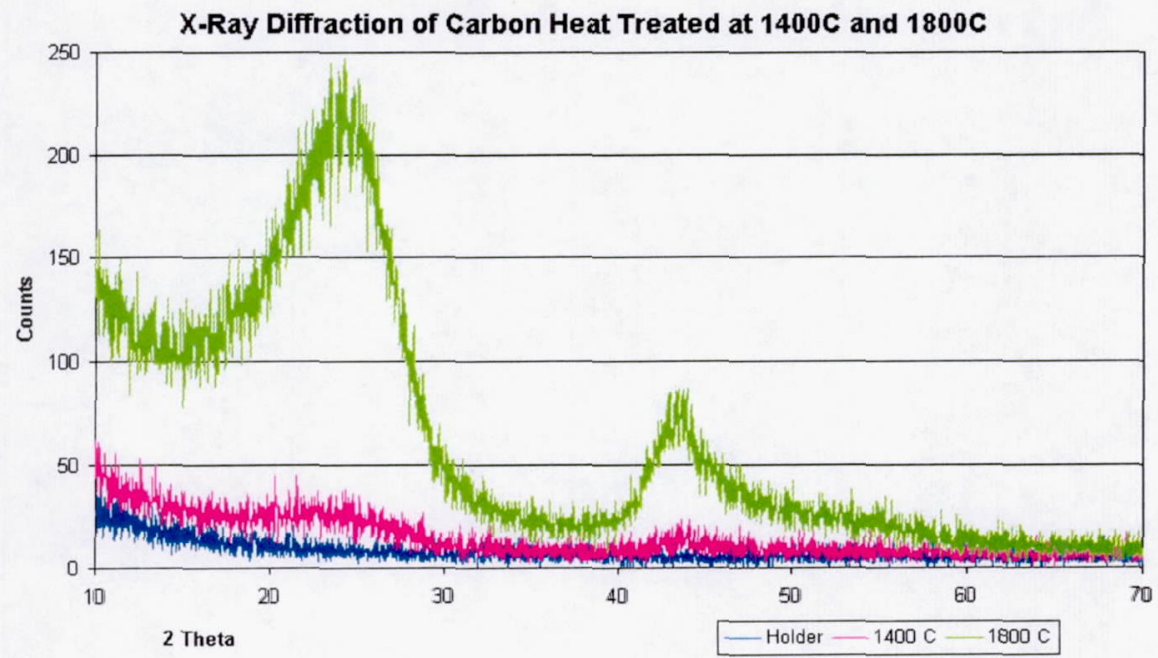

Figure 13. X-ray diffraction scans of samples heat treated at $1400^{\circ} \mathrm{C}$ and $1800^{\circ} \mathrm{C}$ with the carbon sample holder as reference.

Table I. Average Knoop hardness values for tested region in each sample.

\begin{tabular}{|l|c|c|c|}
\hline & \multicolumn{3}{|c|}{ Average Knoop Hardness Value } \\
\hline Sample & $\mathrm{SiC}$ region $(\mathrm{Hk})$ & $\mathrm{Si}$ Region $(\mathrm{Hk})$ & Interface $(\mathrm{Hk})$ \\
\hline Pine, $\|$ to growth direction & 1640 & 1010 & 1440 \\
\hline Jelutong, $\perp$ to growth direction & 1720 & 965 & 1330 \\
\hline Jelutong, $\|$ to growth direction & 1300 & 942 & 1310 \\
\hline Jelutong, $\left(\mathrm{SiC}, 1 \times \mathrm{ZrO}_{2}\right.$ infiltrated) & 1490 & 876 & 1110 \\
\hline Jelutong, $\left(\mathrm{SiC}, 3 \times \mathrm{ZrO}_{2}\right.$ infiltrated) & 1490 & 860 & 1120 \\
\hline Jelutong, $\left(\mathrm{SiC}, 5 \times \mathrm{ZrO}_{2}\right.$ infiltrated) & 1400 & 880 & 1050 \\
\hline Total Average & 1510 & 920 & 1230 \\
\hline Documented Values & 2450 & $950-1150$ & \\
\hline
\end{tabular}




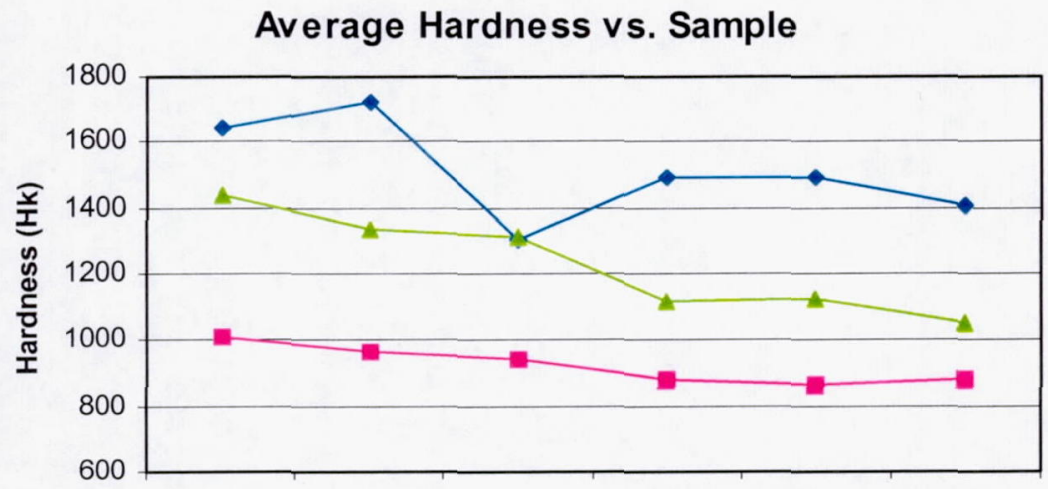

Sample

$$
\multimap \mathrm{SiC} \rightarrow-\mathrm{Si} \longrightarrow \text { Interface }
$$

Figure 13. Plot of average Knoop hardness values of $\mathrm{SiC}, \mathrm{Si}$, and the interface of each sample. 
the difference in attenuation as the bias is varied from -30 to $+30 \mathrm{~V}$ is less than $0.015 \mathrm{~dB}$, excluding two data points. Furthermore, it appears that the attenuation difference, while small, is higher for a positive applied bias. The phase of the $1 \mathrm{~cm}$ long FGC-PPS line varies less than 0.3 degree, which is within normal measurement error.

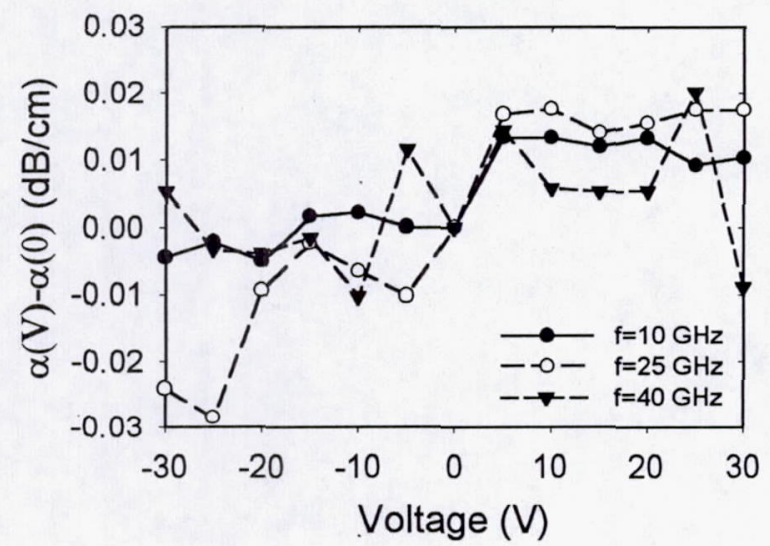

(a)

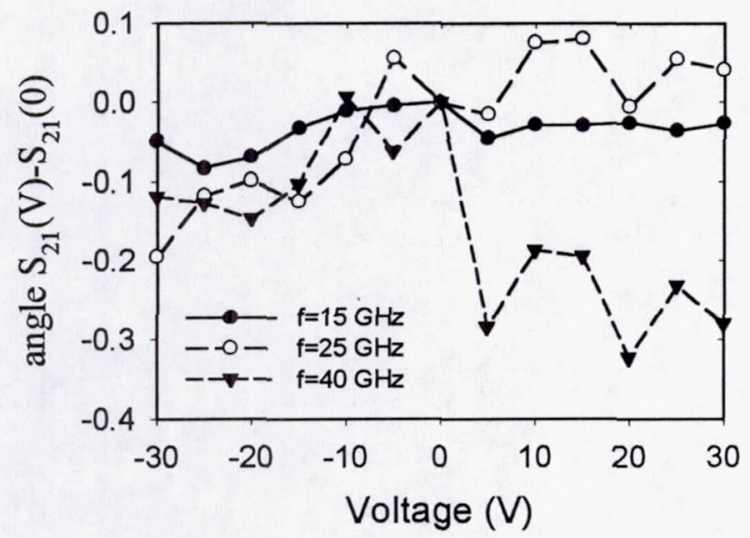

(b)

Figure 7: Measured attenuation and phase of a $1 \mathrm{~cm}$ long FGC-PPS line as a function of applied bias between the center conductor and ground planes.

\section{CONCLUSIONS}

For the first time, Finite Ground Coplanar waveguides fabricated on CMOS grade $\mathrm{Si}$ wafers with a porous silicon and a polyimide interface layer have been characterized. The measured attenuation is $1 \mathrm{~dB} / \mathrm{cm}$ lower than previously reported FGC lines on CMOS grade $\mathrm{Si}$. It is shown that this new transmission line follows the same design rules derived for FGC lines with only a polyimide interface layer. Furthermore, it is shown that the propagation characteristics are not dependent on applied bias.
[1] G. E. Ponchak, "RF transmission lines on silicon substrates," 29 th European Microwave Conference Dig., Munich, Germany, Oct. 5-7, 1999, pp. 158-161.

[2] G. E. Ponchak and L. P. B. Katehi, "Measured attenuation of coplanar waveguide on CMOS grade silicon substrates with a polyimide interface layer," IEE Electronics Letters, Vol. 34, No. 13, pp. 13271329, June 25, 1998.

[3] G. E. Ponchak, E. Dalton, A. Bacon, J. Papapolymerou, and E. M. Tentzeris, "Measured propagation characteristics of finite ground coplanar waveguide on silicon with a thick polyimide interface layer," $32^{\text {nd }}$ European Microwave Conference Dig., Milan, Italy, Sept. 23-27, 2002, pp. 167-170.

[4] R. L. Peterson and R. F. Drayton, "Dielectric properties of oxidized porous silicon in a low resistivity substrate," 2001 IEEE Int. Microwave Symp. Dig. Phoenix, AZ, May 20-25, 2001, pp. 767770 .

[5] I. K. Itotia and R. F. Drayton, "Porosity effects on coplanar waveguide porous silicon interconnects," 2002 IEEE Int. Microwave Symp. Dig. Seattle, WA, June 2-7, 2002, pp. 681-684.

[6] L. T. Canham, Properties of Porous Silicon, London: Institute of Electrical Engineers (UK), 1996.

[7] A. Halimaoui, "Porous silicon: material processing, properties and applications," Porous Silicon Science and Technology, eds. J.-C. Vial and J. Derrien, New York: Springer-Verlag, pp. 33-52, 1995.

[8] J. Leu, H.-M. Ho, J. K. Lee, J. Kasthurirangan, C. N. Liao, and P. S. Ho, "The evaluation of low dielectric constant materials for deep submicron interconnect applications," in Proc. $6^{\text {th }}$ Meeting Dupont Symp. Polyimide Microelectronics, May 1-3, 1995.

[9] Dupont Company Pyralin LX data sheet.

[10] R. B. Marks, "A multiline method of network analyzer calibration," IEEE Trans. Microwave Theory and Techniques, Vol. 39, pp. 1205-1215, July 1991.

[11] G. E. Ponchak, E. Dalton, A. Bacon, J. Papapolymerou, and E. M. Tentzeris, "Measured propagation characteristics of finite ground coplanar waveguide on silicon with a thick polyimide interface layer," $32^{\text {nd }}$ European Microwave Conference Dig., Milan, Italy, Sept. 23-27, 2002, pp. 167-170.

[12] I. K. Itotia and R. F. Drayton, "DC bias effects on bulk silicon and porous silicon substrates," accepted for the 2003 IEEE Ant. And Prop. Symp. Dig., Columbus, OH, June 2003.

\section{REFERENCES}

